\title{
Macropropagation of Dennettia tripetala Baker f.
}

\section{Alfred Ossai Onefeli ${ }^{1 \Xi}$, Adejoke Olukemi Akinyele ${ }^{1}$}

\author{
${ }^{1}$ University of Ibadan, Faculty of Agriculture and Forestry, Department of Forest Resources Management, \\ Ibadan, Nigeria \\ ${ }^{\star}$ Corresponding author: e-mail: ftaxonomist@gmail.com
}

\section{Citation:}

ONEFELI AO, AKINYELE AO 2014 Macropropagation of Dennettia tripetala Baker f. South-east Eur for 5 (2): 135-144. DOI: http://dx.doi.org/10.15177/seefor.14-09

\begin{abstract}
Background and Purpose: Dennettia tripetala Baker $\mathrm{f}$. is a small fruit-producing tree, which both animals and humans depend upon for their survival. Consequently, there is a great pressure on the seed, which is the only alternative for its inexpensive propagation. Hence, the species has been rendered threatened in the forest. Based on this fact, this study examined the macropropagation of Dennettia tripetala in order to domesticate and ensure its continuous availability for human utilization.

Materials and Methods: The propagules (cuttings) used for this study were collected on five year old mother trees in Oloruntele, Ondo State while the experiment was conducted at the Department of Forest Resources Management, University of Ibadan, Nigeria. Cuttings were prepared using two factors; indole butyric acid (IBA) concentrations (0 ppm, 1000 ppm, 2000 ppm and 3000 ppm) and nodal positions (upper, middle and base), set under a high humidity propagator and watered twice a day. The experimental design used was a completely randomized design and the replication was done twice. Data were collected on percentage rooting, number of root per cutting, ramets' height growth, ramets' collar diameter and ramets' leaf number. Statistical analysis was done using ANOVA.

Results and Conclusions: The optimum rooting was observed in 2000 ppm IBA treated cuttings $(95.50 \%)$ and upper nodal cuttings $(72.39 \%)$. ANOVA test shows that hormone concentrations and nodal positions significantly affected the rooting of $D$. tripetala. The study also showed that hormone concentrations and nodal positions do not significantly $(p>0.05)$ determine the ramet's height growth of the species, being that the ramet that had the highest height was $0 \mathrm{ppm}(6.11 \mathrm{~cm})$ and middle nodal position $(5.96 \mathrm{~cm})$. From the findings, $2000 \mathrm{ppm}$ IBA hormone and upper node have been discovered to be the ideal hormone concentration and nodal position at which five year old $D$. tripetala cuttings can be best rooted and survive.
\end{abstract}

Keywords: IBA hormone, hormone concentration, nodal position, stem cutting, Dennettia tripetala Baker $\mathrm{f}$. 


\section{INTRODUCTION}

Dennettia tripetala Baker $f$. belongs to the family Annonaceae. It is a tropical small tree that abounds throughout the rainforest zone of Africa. It is found in the tropical rainforest region of Nigeria and sometimes in Savana areas [1]. This tree flourishes at the onset of rain, from April to June [2].

The fruits of the tree are edible and have a peppery and spicy taste. It serves as mild stimulant and may also serve as a source of some vitamins. The leaves are used to treat mild fever in combination with mango leaves [3]. Pharmacologically, the oil extracted from the fruit of $D$. tripetala is used in the manufacture of mouth wash [3]. Some of the fruit extracts have been shown to be active as antifungal agents against Candida sp., Crytococeus sp., Geotrichum sp., Rhizopus stolonifer, Aspergillus sp. and Fusarium sp. [4]. The fruit also contains an essential oil, which has been used as an effective preservative for stored grains such as cowpea and maize without negatively affecting their viability [5].

Macropropagation involves the use of cuttings in producing clones of large quantity from the ortet for the purpose of conservation [6]. There is dearth of information on the propagation of D. tripetala. However, a lot has been done about the vegetative propagation of tropical African tree species, using simple and inexpensive technologies [6-14]. For instance, Atangana et al. [7] reported that the rooting of most of our indigenous trees occurs between 6-12 weeks of propagation. However, their study only focused on the domestication of Allanblackia floribunda. Also, different authors have worked on the propagation of $D$. tripetala by means of seeds [15-17). However, its macropropagation is very significant as there is too much pressure on the seed of the species, which is the only alternative for achieving inexpensive domestication. According to Osaigbovo et al. [18], D. tripetala has inconsistent fruiting, poor seed germination and slow seedling growth. Within the short period available, maximal number of seeds must be collected before the competition, such as game, cattle and humans.
In macropropagation, various factors have been reported to influence the rooting of cuttings in tree crops out of which hormone concentrations and nodal position are the most important [7]. Tree species vary considerably in the optimal application of hormone and there is also much intraspecific variation [19]. This form of variation is not well understood in most of our indigenous tree species. Tchoundjeu and Leaky [8] reported that the best concentration of auxin IBA for the rooting of African mahogany was found to be $1000 \mathrm{ppm}$. They equally discovered that a greater percentage of cuttings from basal nodes have rooted compared to those from apical nodes. Therefore, nodal position is a significant factor to be considered when carrying out any meaningful vegetative propagation. It is also very important in macropropagation because it determines to a large extent the rooting ability of plant cutting. For some plants, upper node may be the most successful position while some other plants are easily domesticated when the older parts (middle and base) of the cuttings are propagated. Considering the diversity of use of $D$. tripetala, together with its threatened conservation status in the forest, this study investigated the possibility of domesticating the species from cuttings as its source of germplasm.

\section{MATERIALS AND METHODS}

The propagules (i.e. cuttings) used for this study were collected on five year old mother trees in Oloruntele, Ondo State, while the experiment was conducted at the Department of Forest Resources Management, Universit $\mathrm{y}$ of Ibadan, Nigeria. Oloruntele is a village in Ileoluji-Okeigbo Local government, Ondo state. It lies in the dry lowland rainforest belt [20]. The climate is characterized by two seasons i.e. wet and dry seasons. The dry season occurs between November and March while the wet season is usually between April and September.

University of Ibadan is located north of Ibadan along Oyo road at approximate latitude $7^{\circ} 26^{\prime} 42.7308^{\prime \prime} \mathrm{N}$ and longitude 353'57.1560" $\mathrm{E}$. 
It is located at an altitude of $277 \mathrm{~m}$ above the sea level [11]. The climate is the West Africa monsoon with dry and wet seasons. The dry season is usually from November through March and is characterized by dry cold wind of harmattan [11]. The wet season usually lasts from April to October with occasional strong winds and thunderstorms [11].

The cuttings were collected at the upper, middle and basal position on the mother tree species. The leaves of the cuttings were reduced to half of the original sizes and then treated with IBA hormone, prepared into 4 different concentrations (0 ppm, 1000 ppm, 2000 ppm and 3000 ppm) using quick deep method [11, 21-22]. The cuttings were set in seed plastic trays containing sterilized river sand. Each of the treatment contained 12 cuttings. Replication was made twice making an aggregate of 288 cuttings. The experiment was arranged in a completely randomized design (CRD) under a high humidity propagator. Watering of the set cuttings was carried out twice a day using a knapsack sprayer. The cuttings were monitored for a period of twelve weeks. During this period, a number of rooted cutting, number of sprouted cutting, number of survived cutting, number of root per cutting was obtained by visual counting. In addition, length of root per cutting was measured using a meter rule. From these results, percentage rooting, percentage sprouting, and percentage survival were estimated. After twelve weeks of monitoring the cuttings under a high humidity propagator, rooted cuttings were transplanted into polythene pots filled with top soil and assessed every day for another twelve weeks. Hence, measurement of height of ramets was accomplished with a meter rule, while collar diameter was measured with vernier caliper and number of leaf was achieved with visual counting.

One-way ANOVA was used to test differences between mean values of measured characteristics between the treatments. Mean values were separated using Fisher's Least's Significance Difference (LSD) test, with significance level of $p<0.05(\alpha=0.05)$.

\section{RESULTS}

All the hormone treatments had increased sprouted cuttings right from the first measurement period ( 2 weeks after planting) to the fifth measurement (10 weeks after planting) and stabilized at sixth measurement period (12 weeks after planting) (Figure 1). At first measurement (2 weeks after planting), none of the cuttings treated with 3000 ppm IBA and those without treatment sprouted (Figure 1), whereas about $4.86 \%$ and $1.38 \%$ of cuttings treated with $2000 \mathrm{ppm}$ and 1000 ppm IBA, respectively, have sprouted. At the end of the experiment, 2000 ppm IBA treated cuttings have also produced the highest sprouting percentage (89.44\%) while 3000 ppm IBA treated cuttings had the lowest sprouting percentage (33.19\%). Hormone concentration (HC) had significant effect $(p<0.05)$ on the sprouted cuttings of $D$. tripetala (Table 1).

Regarding the cuttings' nodal positions, there was a gradual increment in the percentage sprouted cuttings from first to fifth measurement period, after which there was a period of stabilization in the sprouted cuttings (Figure 1). Results show that cuttings taken from the upper nodal position had the best sprouting percentage right from the first period of measurement to the end of the experiment (Figure 1). The final measurement results (Figure 1) revealed that $70.52 \%$ upper nodal cuttings sprouted, while only $58.64 \%$ and $53.22 \%$ of the middle and basal cuttings correspondingly were able to sprout. Similar to the results obtained from $\mathrm{HC}$, the percentage sprouted cuttings of $D$. tripetala from different NP were significantly different $(p<0.05)$ (Table 1$)$.

Considering the effect of $\mathrm{HC}$ on rooting of D. tripetala, $2000 \mathrm{ppm}$ IBA treated cuttings rooted best $(95.50 \%)$, this was closely followed by 1000 ppm (72.22 \%), 0 ppm (51.25\%) while the 3000 ppm IBA treated cuttings ended up having the least rooting percentage (Table 1). There was significant difference $(p<0.05)$ in percentage rooted cuttings among the four levels of $\mathrm{HC}$. Effect of the nodal position (NP) was significant on the rooted cuttings. Upper nodal cuttings (72.39\%) rooted more than middle $(62.81 \%)$ and basal (54.58 \%) nodal cuttings. 
Root length significantly increased with an increase in hormone concentration (Table 1). In other words, the root length of 3000 ppm IBA treated cuttings $(6.31 \mathrm{~cm})$ were more than those of $2000 \mathrm{ppm}(5.79 \mathrm{~cm})$, $1000 \mathrm{ppm}(4.21 \mathrm{~cm})$ and $0 \mathrm{ppm}(2.90 \mathrm{~cm})$.
With respect to the NP, upper nodal cuttings had the highest root length $(5.70 \mathrm{~cm})$, followed by the middle $(4.91 \mathrm{~cm})$ and the base $(3.80 \mathrm{~cm})$. Significant difference $(p<0.05)$ was also observed in root length among the nodal positions.

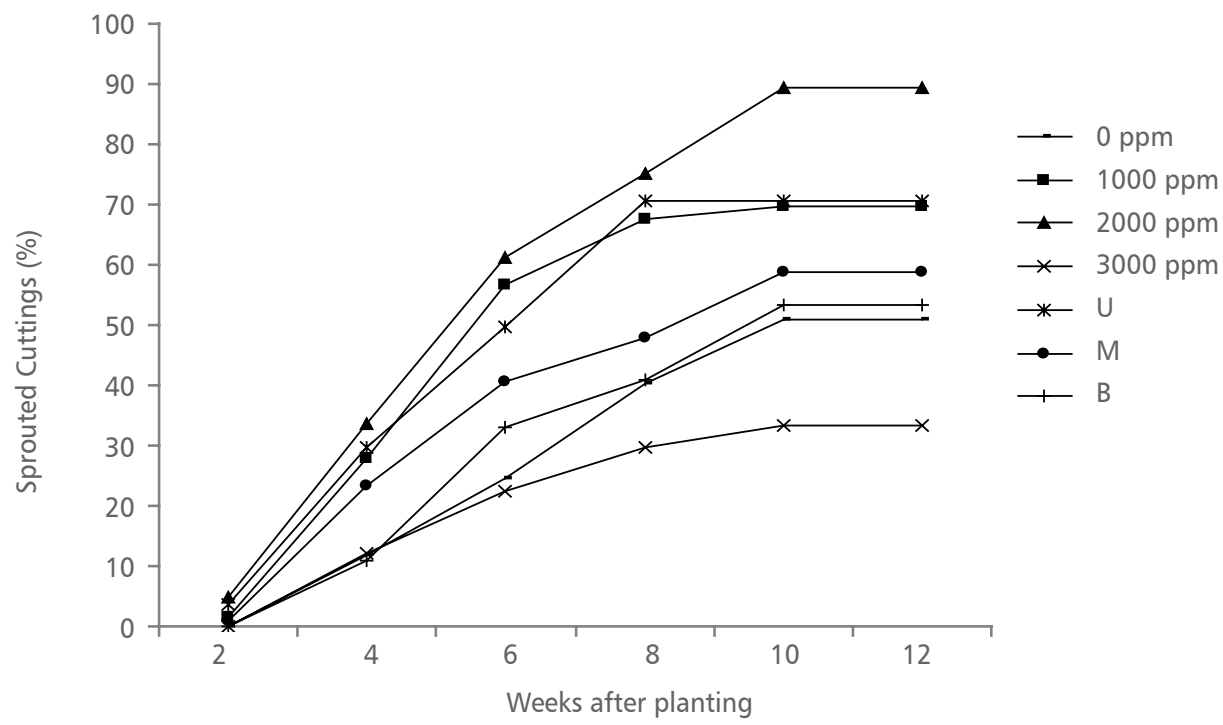

FIGURE 1. Sprouting of $D$. tripetala cuttings using different IBA hormone concentrations and nodal positions $(U=$ upper node, $M=$ middle node and $B=$ basal node)

TABLE 1. Effect of hormone and nodal positions on rooting, sprouting, survival and growth of D. tripetala

\begin{tabular}{|c|c|c|c|c|c|c|}
\hline $\begin{array}{c}\text { Hormone } \\
\text { concentration }\end{array}$ & $\begin{array}{l}\text { SC } \\
(\%)\end{array}$ & $\begin{array}{l}\text { RC } \\
(\%)\end{array}$ & $\begin{array}{c}\mathbf{S} \\
(\%)\end{array}$ & $\begin{array}{c}\mathbf{R L} \\
(\mathrm{cm})\end{array}$ & $\begin{array}{l}\text { RH } \\
(\mathrm{cm})\end{array}$ & $\begin{array}{l}\text { RCD } \\
(\mathrm{cm})\end{array}$ \\
\hline $0 \mathrm{ppm}$ & $50.83 b$ & $51.25 b$ & $69.79 a$ & $2.90 a$ & 6.11 & 0.704 \\
\hline 1000 ppm & $69.72 c$ & $72.22 c$ & $80.38 b$ & $4.21 \mathrm{~b}$ & 5.76 & 0.612 \\
\hline 2000 ppm & $89.44 d$ & $95.50 d$ & $84.85 b$ & $5.79 c$ & 5.82 & 0.586 \\
\hline 3000 ppm & $33.19 a$ & $37.08 a$ & $84.72 b$ & $6.31 c$ & 5.79 & 0.687 \\
\hline$p$-value & $0.000 *$ & 0.000 * & $0.002 *$ & $0.000 *$ & $0.439 \mathrm{~ns}$ & $0.055 \mathrm{~ns}$ \\
\hline \multicolumn{7}{|l|}{$\begin{array}{c}\text { Nodal } \\
\text { position }\end{array}$} \\
\hline U & $70.52 c$ & $72.39 c$ & $65.52 a$ & $5.70 c$ & 5.93 & $0.608 a$ \\
\hline$M$ & $58.64 b$ & $62.81 b$ & $79.50 b$ & $4.91 b$ & 5.96 & $0.610 a$ \\
\hline B & $53.22 \mathrm{a}$ & $54.58 a$ & $94.79 c$ & $3.80 a$ & 5.72 & $0.724 b$ \\
\hline p-value & $0.000^{*}$ & 0.000 * & $0.000^{*}$ & $0.000^{*}$ & $0.472 \mathrm{~ns}$ & $0.012^{*}$ \\
\hline
\end{tabular}

Means with similar alphabet within the same column of any set of treatments are not significantly different at $p=0.05$ SC - sprouted cuttings; RC - rooted cuttings; S - survival; RL - root length; RH - ramet height; RCD - ramet collar diameter; U - upper; $\mathrm{M}$ - middle; $\mathrm{B}$ - base

* - significant $(p<0.05)$; ns - not significant $(p>0.05)$ 
Result shows that most $(84.85 \%)$ of the rooted cuttings treated with 2000 ppm IBA finally survived during the period of the study (Table 1 ). In the same vein, approximately $85 \%$ of the rooted 3000 ppm IBA treated cuttings survived. In the case of $1000 \mathrm{ppm}$ and $0 \mathrm{ppm}$ IBA treated cuttings, $80.38 \%$ and $69.79 \%$ of the rooted ones survived, respectively. There was significant difference $(p<0.05)$ in the survived cuttings from the different hormone concentration. Cuttings from the basal positions survived more $(94.79 \%)$ than the ones collected at the middle $(79.50 \%)$ and the upper nodes (65.52 \%). Nodal position significantly affected the percentage survived cuttings ( $p<0.05$ ).

Figure 2 shows that number of root produced in the species increased as the concentration of hormone increased. Cuttings treated with 0 ppm, 1000 ppm and 2000 ppm had approximately 3 roots each on the average while the 3000 ppm IBA treated cuttings produced an average root number of about 4. Root number did not significantly depend on the concentration of the hormone applied ( $p>0.05$ ) (Table 2). Conversely, root number significantly depends on the nodal position of the cuttings ( $p<0.05$ ) (Table 2 ), with the basal cuttings having the highest average root number (4.38), followed by middle cuttings (3.66) and upper cuttings (1.72) (Figure 2).

Furthermore, slight increments in height and collar diameter of $D$. tripetala ramets were recorded during the weeks of measurement throughout the study period (Figure 3 and Figure 4). Hormone concentration did not

TABLE 2. Effect of hormone concentration and nodal position on root and leaf production of D. tripetala

\begin{tabular}{cccc}
\hline Variable & $\begin{array}{c}\text { Chi-square } \\
\text { value }\end{array}$ & df & p-value \\
\hline N.P. VS R.N. & 17.45 & 4 & $0.002^{*}$ \\
H.C. VS R.N. & 8 & 6 & $0.238 \mathrm{~ns}$ \\
N.P. VS N.L. & 25.9 & 8 & $0.001^{*}$ \\
H.C. VS N.L. & 20.35 & 12 & $0.061 \mathrm{~ns}$ \\
\hline
\end{tabular}

NP - nodal positions; HC - hormone concentrations; NR number of root; NL - number of leaf

* - significant $(p<0.05)$; ns - not significant $(p>0.05)$

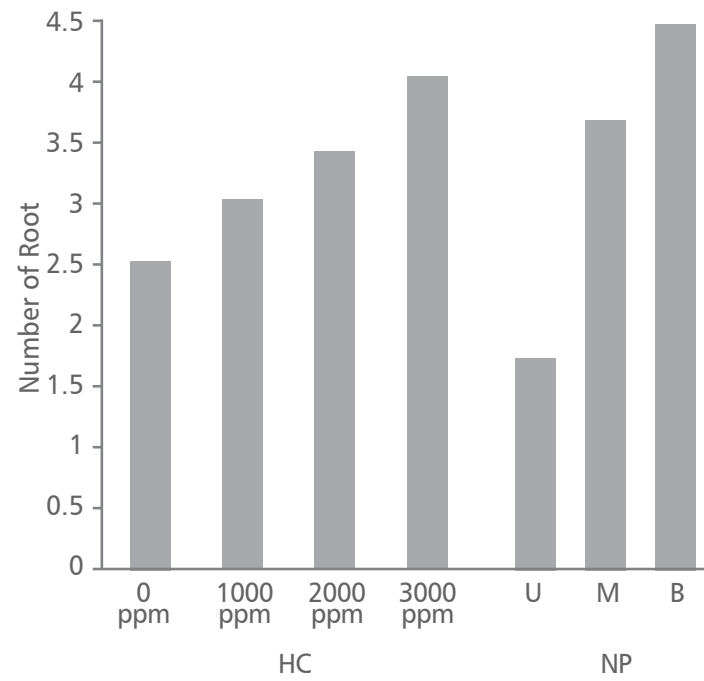

FIGURE 2. Number of root produced in $D$. tripetala cuttings using different IBA hormone concentrations (HC) and nodal positions (NP) $(\mathrm{U}=$ upper node, $\mathrm{M}=$ middle node and $\mathrm{B}=$ basal node)

have significant effect, $(p>0.05)$ (Table 1) on the ramets' height. At the initial stage of measurement (i.e. week 2), ramets that received the IBA treatment of $3000 \mathrm{ppm}$ had the highest height growth rate of $2.01 \mathrm{~cm}$ (Figure 3). But at week 4, the highest growth $(2.83 \mathrm{~cm})$ was observed in cuttings with no hormone treatment, while at week 6 , it was found in $2000 \mathrm{ppm}$ ramets (Figure 3). At the $12^{\text {th }}$ week, $0 \mathrm{ppm}$ produced ramets that had the highest growth $(6.11 \mathrm{~cm})$ (Figure 3$)$. However, the effect of nodal positions was not significant ( $p>0.05$ ) (Table 1) on the height growth of the species. At the first measurement period, the average height of ramets from the basal node was $2.45 \mathrm{~cm}$, middle node $(2.02 \mathrm{~cm})$ and upper node $(1.21 \mathrm{~cm})$ (Figure 3$)$. In the $12^{\text {th }}$ week after transplanting, middle nodal ramets had the highest height $(5.96 \mathrm{~cm})$, they are followed by upper nodal ramets $(5.93 \mathrm{~cm})$ and the base nodal ramets $(5.72 \mathrm{~cm}$ ) (Figure 3 ).

The result obtained from the effect of hormone concentration on ramet collar diameter followed the same pattern as the ramet height, in that that there was no significant difference $(p>0.05)$ among the 
collar diameter of different hormone treatments (Table 1). Also, the effect of nodal positions was significant $(p<0.05)$ on the collar diameter, with ramets from the basal nodes having the highest collar diameter size $(0.72 \mathrm{~cm})$ at the final measurement and they were closely followed by ramets from the middle $(0.61 \mathrm{~cm})$ and upper nodes $(0.60 \mathrm{~cm})$ (Table 1 and Figure 4).

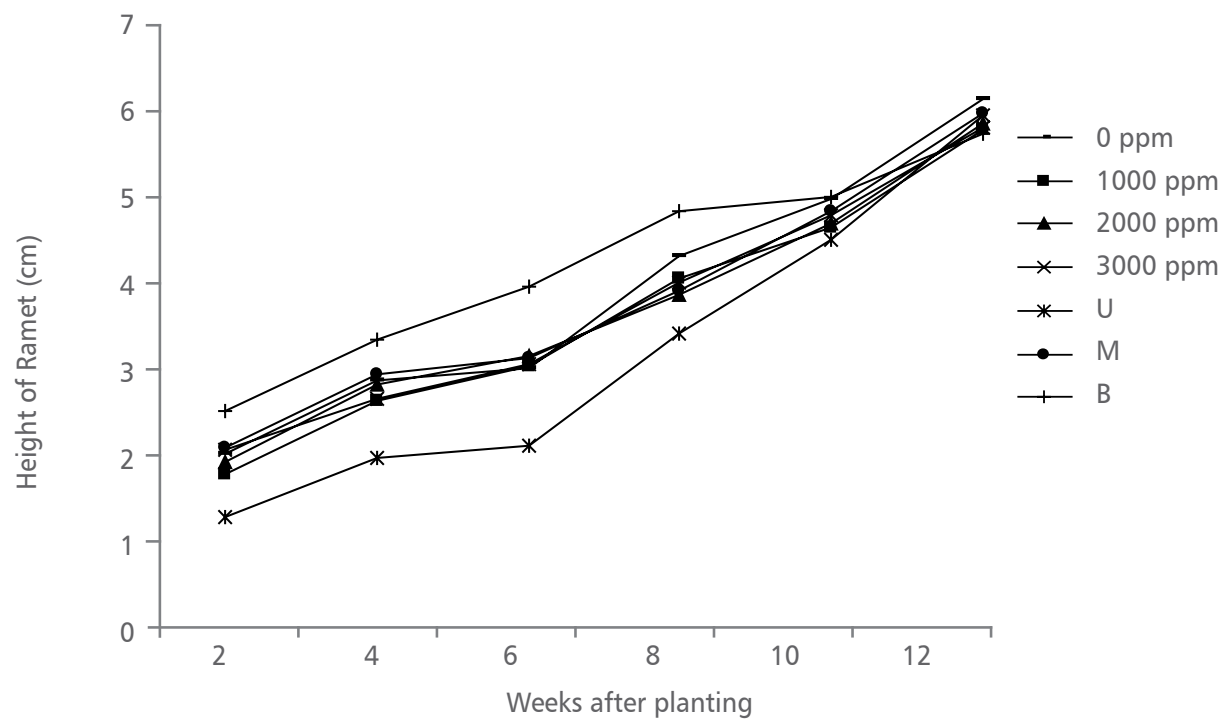

FIGURE 3. Height growth of $D$. tripetala's Ramets using different IBA hormonne concentrations and nodal positions ( $U=$ upper node, $M=$ middle node and $B=$ basal node)

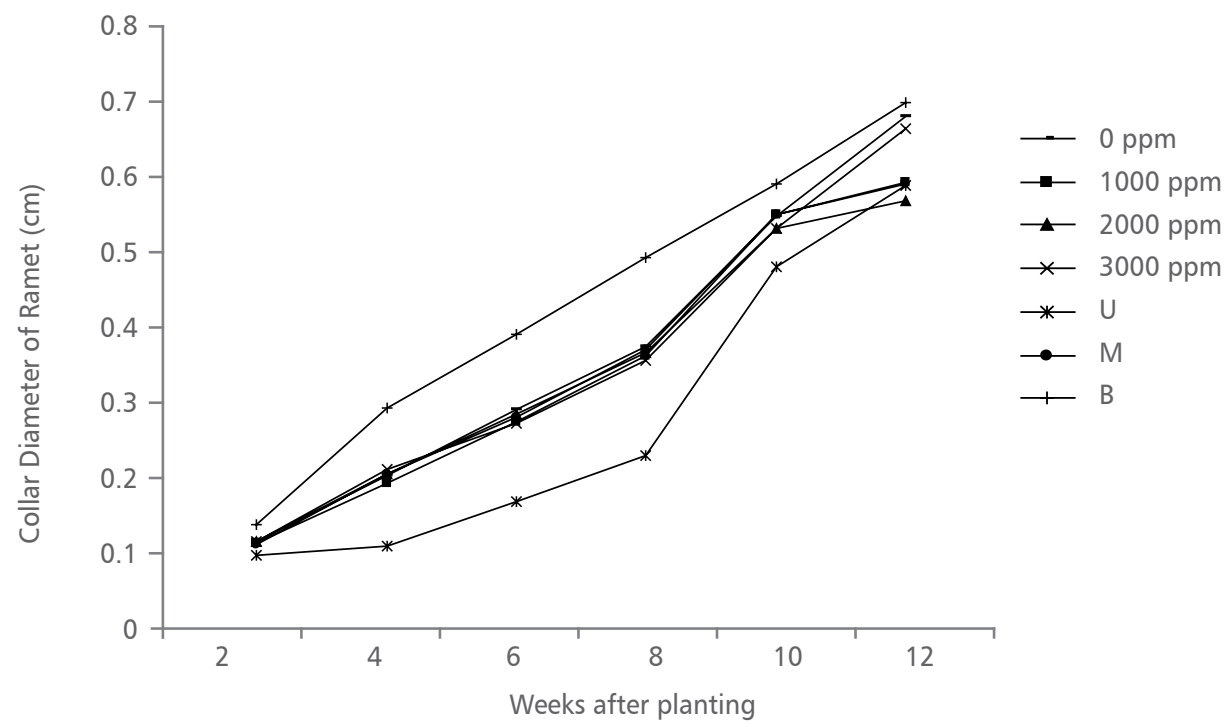

FIGURE 4. D. tripetala ramets collar diameter increament using different IBA hormone concentrations and nodal positions $(\mathrm{U}=$ upper node, $\mathrm{M}=$ middle node and $\mathrm{B}=$ basal node) 
Results of leaf production in D. tripetala are shown in Figure 5 and Table 2. Ramets obtained from cuttings treated with 3000 ppm IBA produced an average number of 3 leaves while ramets from the remaining treatments (i.e. 0 ppm, 1000 ppm and 2000 ppm) only had about 2 leaves on them. Leaf production did not significantly $(p>0.05)$ depend on hormone concentration (Table 2). Ramets from the basal nodes had the highest leaf production, with about 3 leaves while the ramets from upper nodes had the least number of leaves produced (2). Significant difference $(p<0.05)$ was observed in this leaf number among the nodal positions (Table 2).

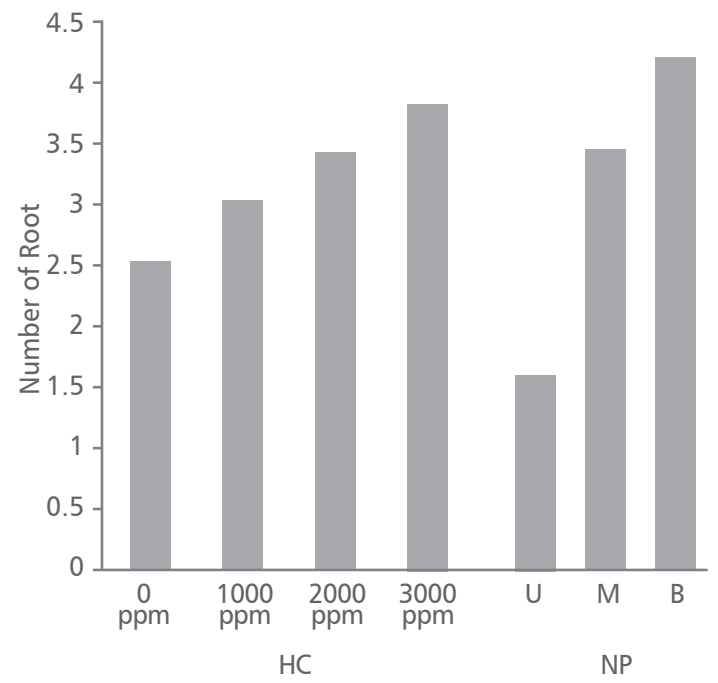

FIGURE 5. D. tripetala ramets leaf production using different IBA hormone concentration (HC) and nodal positions (NP) ( $U=$ upper node, $M=$ middle node and $B=$ basal node)

\section{DISCUSSION}

From the presented results it can be concluded that the best level of exogenous $\mathrm{HC}$ needed to obtain an optimum sprouting of $D$. tripetala is $2000 \mathrm{ppm}$. The decrease in the number of sprouted cutting as the $\mathrm{HC}$ is increased above 2000 ppm may however be attributed to the fact that there is a toxic level of auxins with which $D$. tripetala as well as other indigenous medicinal trees will not be able to undergo physiological process that will result with root production [8]. Therefore, any further increase in the $\mathrm{HC}$ above this level eventually inhibits the number of sprouted cuttings from the species.

Similar results obtained from this study have been reported by Lee and Bilderback [23], who emphasized that there was a significant increase in the number of sprouted cuttings of Heptacodium jasminoides Airy Shaw, as the IBA hormone concentration increased from $0 \mathrm{ppm}$ to $7500 \mathrm{ppm}$. They concluded that an additional increase in the hormone concentration above $7500 \mathrm{ppm}$ resulted in reduction of the number of sprouted cuttings. In Ginkgo biloba L. IBA at $4000 \mathrm{ppm}$ increased the percentage of sprouting in stem cuttings, but higher concentration decreased it [24]. Study by Saffari and Saffari [13] showed that an increase in IBA concentration above 4000 ppm resulted in a decreased percentage of sprouting of Dodoneae viscosa L. cuttings.

The higher number of sprouted cuttings observed from the upper NP than that from middle and basal nodes may be due to closeness of the upper nodes cuttings to the meristematic part of the plants, where the endogenous hormones are naturally produced and therefore aided the cell differentiation that resulted in the sprouting of the cuttings. According to Tchoundjeu and Leaky [8], auxins are basipetally translocated in plant's stems, and are largely responsible for the polarity of shoot.

The $95.5 \%$ rooted cuttings recorded in this study, which was more than some of the previous works of other authors such as Abdullah et al. [25] is a significant success. The results from the present study imply that higher concentrations of IBA (3000 ppm) decreased rooting percentages and caused desiccation of cuttings of $D$. tripetala. This is possibly due to a phytotoxic effect of this hormone in tandem with high concentrations of endogenous auxins in cuttings of $D$. tripetala. The application of exogenous auxins may have led to supra-optimal concentrations in plant tissues, but with negative effects on rooting. It has also been suggested that the optimum 
concentration of auxins is favorable, while supra-optimum auxin levels are toxic to the root regeneration [26]. When IBA is applied in high concentrations to cuttings with high concentration of endogenous hormone, it has an herbicidal effect [27].

Although auxins have been successfully used to promote rooting of hardwood cuttings [28-29], the rooting of dipterocarp cuttings without auxins have been previously reported [30]. Most of the upper node cuttings used for this study were juvenile. Juvenility may be an important factor in the rooting potential of dipterocarp cuttings [31]. Juvenile tissues of woody plants tend to have higher levels of endogenous auxins and are less differentiated (and therefore more prone to re-differentiation) [27].

Findings from this study indicated that survival of $D$. tripetala is closely related to its rooting system, which is also dependent on the concentration of the exogenous hormone applied. Although, it was observed that too high concentration of exogenous hormone is detrimental to the rooting of the species, but those that were able to root ended up surviving. The results corroborate Atangana et al. [7], who reported that application of exogenous hormone significantly increased the percent survival and rooting of Caesalpinia bonduc (L.) Roxb.

The higher percentage of survival and number of roots from the basal section indicated that the basal stem part cutting might support a more optimal rooting and survival compared to cuttings from medial and apical sections. The carbohydrate content and related hormones predictably gave significant influences on these conditions. In the basal part, such phyto-hormone and carbohydrate as a source of energy was sufficient for optimal root formation after the bud dormancy breaking. These more favorable conditions might accelerate cell division and further differentiation for root and shoot initiation and formation [32].

The results from the early growth stage of this study have shown that $D$. tripetala is a slow growing species. It also implies that exogenous hormone applied at cuttings preparation stage reduces with time and therefore has negligible effects on the species growth once it has reached the ramet stage. According to Carey [10], more height growth was observed in Salvia nemorosa L. without exogenous hormone than those that were treated 4 weeks after transplanting. It has also been reported by Boyle [33] that, as plants grow older, the activities of the auxins in it tend to be diverse. When talking about the effects of the nodal position on the diameter growth, the difference is insignificant, if the assessment period is extended to more than the twelve weeks after transplanting. Therefore, more of the auxins are being utilized for other physiological process such as branching than in height and diameter growth. For instance, authors [34-35] have reported that Cytokinins induce branching in many plants.

\section{CONCLUSIONS}

The study discovered that $2000 \mathrm{ppm}$ IBA is the optimum concentration at which five year old $D$. tripetala cuttings can be best sprouted, rooted and survive. Also, upper node was seen as the nodal position with the highest mass propagation potential. In addition if ramet's growth of the species is to be considered, hormone concentration is not a significant factor.

Utilization of single node cuttings is therefore beneficial for mass propagation of $D$. tripetala, in that that it will reduce pressure and competition on the fruit, which is the most important part used by both humans and wildlife. It is also generally more cost effective compared to the micropropagation, which is another alternative for clonal production [27].

The significant differences observed in the factors considered in macropropagation of $D$. tripetala can therefore be tapped and used for any other indigenous fruit and medicinal forest tree species. 


\section{REFERENCES}

1. OKWU DE, MORAH FNI, ANAM EM 2000 Isolation and characterization of phenanthrenic alkaloid uvariopsine from Dennettia tripetala fruits. J Med Arom Plant Sci 27: 496-498.

2. UMOH IB 1998 Commonly used fruits in Nigeria. In: Osagie AU, Eka OU (eds) Nutritional quality of plant foods. University of Benin, Trinity press, Benin City, Nigeria, pp 84-120.

3. NWINUKA NM, NWILOH BI 2009 Physicochemical Properties and Fatty Acid Composition of Dennettia tripetala Fruit Oil (Pepper Fruit). Nigerian Journal of Biochemistry and Molecular Biology 24 (1): 42-46

4. EJECHI BO, NWAFOR OE, OKOKO FJ 1999 Growth inhibition of Tomato-rotfungi by phenolic acids and essential oil extracts of pepper fruit. Food Res Int 32 (6): 39-59. DOI: http://dx.doi.org/10.1016/ S0963-9969(99)00057-5

5. AKINWUMI FO 2011 Evaluation of some plant materials for the control of smoked fish pest, Dermestes maculatus degeer (Coleoptera: Dermestidae) in Clarias gariepinus Burchell (Pisces: Clariidae). ARPN J Agric Bio Sci 6 (7): 65-69

6. LEAKEY RRB 2004 Physiology of vegetative reproduction. In: Burley J, Evans E, Younquist JA (eds) Encyclopaedia of Forest Sciences. Academic Press, London, UK, pp. 1655-1668. DOI: http:// dx.doi.org/10.1016/B0-12-145160-7/00108-3

7. ATANGANA AR, TCHOUNDJEU AZ, ASAAH A.K, SIMONS CAJ, KHASA BA 2006 Domestication of Allanblackia floribunda: Amenability to vegetative propagation. Forest Ecol Manag 237 (1-3): 246-251. DOI: http://dx.doi.org/10.1016/j. foreco.2006.09.081

8. TCHOUNDJEU Z, LEAKEY RRB 2006 Vegetative propagation of African mahogany: effects of auxin, node position, leaf area and cutting length. New Forest 11 (2): 125-136. DOI: http://dx.doi. org/10.1007/BF00033408

9. KURAKAWA T, UEDA N, MAEKAWA M, KOBAYASHI K, KOJIMA M NAGATO Y, SAKAKIBARA H, KYOZUKA J 2007 Direct control of shoot meristem activity by a cytokinin-activating enzyme. Nature 445 (7128): 652-655. DOI: http://dx.doi.org/10.1038/ $\underline{\text { nature } 05504}$
10. CAREY DJ 2008 The Effects of Benzyladenine on Ornamental Crops. MSc thesis, Graduate Faculty of North Carolina, State University Master of Science Horticultural Science Raleigh, North Carolina, USA, $88 \mathrm{p}$

11. AKINYELE AO 2010 Effects of growth hormones, rooting media and leaf size on juvenile stem cuttings of Buchholzia coriacea Engler. Annals of Forest Research 53 (2): 127-133.

12. AKWATULIRA F, GWALI S, OKULLO JBL, SSEGAWA $P$, TUMWEBAZE SB, MBWAMBO JR., MUCHUG A 2011 Influence of rooting media and indole-3butyric acid (IBA) concentration on rooting and shoot formation of Warburgia ugandensis stem cuttings. African Journal of Plant Science 5 (8): 421-429

13. SAFFARI M, SAFFARI VR 2012 Effects of media and indole butyric acid (IBA) concentrationson hopbush (Dodoneae viscosa L.) cuttings in green house. Annals of Forest Research 55 (1): 61-68

14. ONEFELI AO, AKINYELE AO 2013 Effect of Hormone and Nodal positions on Stem cuttings of $P$. angolensis Welw. and $Z$. xanthoxyloides Lam. Agriculture and Forestry 59 (2): 127-135

15. MAPONGMETSEM PM 2007 Pycnanthus angolensis (Welw.) Warb. In: van der Vossen HAM, Mkamilo GS (eds). PROTA 14: Vegetable oils/ Oléagineux. PROTA, Wageningen, Netherlands, pp 38-44

16. ORWA C, MUTUA A, KINDT R, JAMNADASS R, SIMONS A 2009 Agroforestree Database: a tree reference and selection guide version 4.0. World Agroforestry Centre, Kenya. URL: http://www. worldagroforestry.org/resources/databases/ agroforestree (20 February 2014)

17. UDO IO 2011 Potentials of Zanthoxylum xanthoxyloides (LAM.) for the control of stored product insect pests. Journal of Stored Products and Postharvest Research 2 (3): 40-44

18. OSAIGBOVO AU, NWAOGUALA CNC, FALODUN JE 2010 Evaluation of potting media for the production of pepper fruit (Dennetia tripetala) seedlings. Afr J Gen Agr 6 (2): 18-24

19. ALEJANDRO $A$, MARIO PB, ALEJANDRO $M$, LEONARDO G 2009 Vegetative propagation of patagonian cypress, a vulnerable species from the subantarctic forest of South America. Bosque 30 (1): 18-26. DOI: http://dx.doi.org/10.4067/S0717$\underline{92002009000100004}$ 
20. KEAY RWJ 1989 Trees of Nigeria. Clarendon Press Oxford, UK, $337 \mathrm{p}$

21. ONI O 1987 Effect of auxins on the rooting of stem cuttings of Terminalia superba Engel. and Diels. In Oguntala AB (eds). The Role of Forestry in a Depressed Economy: Proceedings of the 17th Annual Conference of the Forestry Association of Nigeria, pp 6-10

22. GBADAMOSI AE, ONI O 2005 Macropropagation of an Endangered Medicinal plant, Enantia chlorantha oliv. Journal of Arboriculture 31(2): 78-82

23. LEE CC, BILDERBACK TE 1990 Propagation of Hepfacodium jasminoides Airy-Shaw by Softwood and Semi-hardwood Cuttings. J Environ Hort 8 (3):121-123

24. BARZGAR TL 2003 The effects of medium and different concentration of IBA on Ginkgo biloba cuttings. MSc thesis, University of Tehran, Iran, 72 p.

25. ABDULLAH ATM, HOSSAIN MA, BHUIYAN MK 2005 Propagation of Latkan (Baccaurea sapida Muell.Arg.) by Mature Stem Cutting. Res J Agric and Biol Sci 1 (2): 129-134

26. AVANZATO DG, COUVILLON A, POKORNY FA 1998 The influence of $p$ - IIB (Phenyl indole 3thiolobutyrate ), Aryl ester of IBA, on the rooting of "Red haven" peach. Acta Hort 227: 197-201

27. HARTMANN HT, KESTER E, DAVIES FT 1990 Plant Propagation. Principles and Practices. Fifth edition, Prentice-Halt International Edition, New Jersey, USA $645 p$
28. TEKLEHAIMANOT Z, MWANG'INGO PL, MUGASHA AG, RUFFO CK 2004 Influence of the origin of stem cutting, season of collection and auxin application on the vegetative propagation of African Sandalwood (Osyris lanceolata) in Tanzania. South Afr For J 201: 13-24

29. AMRI E 2010 Viable options and factors in consideration for low cost vegetative propagation of tropical trees. Int J Bot 6: 1-7. DOI: http://dx. doi. org/10.3923/ijb.2010.187.193

30. AMINAH HA 1990 A note on the rooting of Shorea bracteolata stem cuttings. Journal of Tropical Forest Science 3 (2): 187-188.

31. KURNIAWAN B 2011 Conventional propagation of several Aglaonema accessions using split singlebud stem cutting. J Agrivigor 10 (2): 99-104

32. PROTACIO CM, OBMERGA LR, SIAR SV 2002 Propagation of Mussaenda by stem cutting. Agric Sci 82 (3): 251-259

33. BOYLE TH 1992 Modification of plant architecture in 'Crimson Giant' Easter cactus with benzyladenine. J Amer Soc Hort Sci 117 (4): 584589

34. KHADEMI M, KHOSH-KHUI M 1977 Effect of growth regulators on branching, flowering, and fruit development of ornamental pepper (Capsicum annuum L.). J Amer Soc Hort Sci 102 (6): 796-798

35. WILSON MR, NELL TA 1983 Foliar applications of BA increases branching of 'Welkeri' Dieffenbachia. Hort Sci 18 (4): 447-448 